\title{
Percurso pela África e por Macau, de Benilde Justo Caniato
}

\author{
Elisa GUIMARÃes \\ Universidade de São Paulo / Universidade Presbiteriana Mackenz̦ie
}

livro Percursos pela África e por Macau, de autoria de Benilde Justo Caniato, reúne uma série de onze ensaios publicados em atas, jornais e revistas brasileiras e portuguesas - comprovantes da participação efetiva da autora nos seminários, encontros e congressos diversos, realizados no Brasil e no exterior.

Em expressivo recorte, escritores portugueses e africanos inspiram aos ensaios uma espécie de suma literária em que se cruzam e entrecruzam, num enclave sucessivo, os fios de uma rede de idéias e de formas. Teia habilmente tecida em várias pistas que se misturam e se recobrem na coexistência de instâncias múltiplas do processo criador.

Porque amplos os horizontes abarcam um sem-número de investigações. E os ensaios - independentes, mas intercomunicantes -, vistos em perspectiva, vão-se abeirando uns dos outros.

O eixo das indagações é, em primeiro plano, a língua portuguesa - valor completado por toda uma constelação de referências, ora de ordem histórica, ora de ordem política ou de natureza artística.

Mergulhada nessas referências, a autora desvenda manifestações lingüísticas configuradas em processos diversos, por exemplo, a coexistência, em Cabo Verde, de duas línguas: a portuguesa e a cabo-verdiana ou crioulo. Registra-se a mesma situação de bilingüismo na Guiné-Bissau onde, segundo a autora, “o português é usado quase que exclusivamente na escrita”. (p. 17)

$\mathrm{Na}$ medida em que evolui o exercício investigativo-crítico que enforma a obra, o leitor passa a depreender a coexistência e interpenetração de aspectos lingüísticos que ajudaram a plasmar a nacionalidade - a língua propondo-se como fator de identidade das regiões por onde circula, como expressão indisfarçável da identidade cultural de um povo; e o texto, pelo crivo da aná- 
lise, expressa-se como produtível e interpretável em conexão estrutural com um extratexto, conjunto de fatores históricos, reais ou convencionais, em que o próprio texto se integra. Esses acordes ressoam ao longo da obra inteira, realimentando-a com seu tema obsedante: o processo de identificação nacional na cultura dos países africanos de língua portuguesa.

Assim, traça-se uma rede de relações inesgotáveis comprometidas entre si pelo vínculo da língua, aqui considerada, como a própria autora concebe, como "suporte de cultura literária".

A estudiosa da cultura dos países africanos e de Macau, a quem interessa desvendar e apresentar, por meio da matéria-prima que andou garimpando, as manifestações dessa cultura literária, deixa-se enlevar no moto-perpétuo da beleza da palavra construtora da literariedade do texto. Debruça-se, então, sobre obras e autores, apontando a riqueza das variações da Língua Portuguesa, iluminando as incógnitas e desmistificando o impenetrável. Explora, assim, em lúcida análise, a produção literária de autores como Manuel Ferreira, Luandino Vieira, Arnaldo Santos, Boaventura Cardoso, Garcia Bires - autores para quem a arte é resgate, forma mágica de recriar o mundo e desvelar o real.

Os recursos expressivos de que se valem esses autores situam-nos em conivência tácita, senão em perfeita osmose, com a poesia, mesmo quando se manifestam em prosa. Prosa poética, sem dúvida. Incluem-se, por certo, no número daqueles escritores para os quais a linguagem compõe a realidade artística da obra literária.

A atividade investigativa e crítica da autora empresta à obra Percursos pela África e por Macau, à luz dos ensinamentos transmitidos, bem como das análises efetuadas com ponderação e meticulosidade, traços que despertam o leitor para a singularidade do fenômeno da linguagem, para as dimensões da diferenciação lingüística, para as tonalidades do estilo, para as inter-relações entre os contextos lingüísticos ou não-lingüísticos.

Trata-se, pois, de uma obra a ser considerada como parte do que tem sido chamado "filologia literária", ou seja, a interpretação da literatura à luz da estrutura lingüística e de sua história.

Então, e por isso mesmo, o leitor desfruta de uma série de ensaios que, também pela finura das propostas, torna possível um debate fecundo e criador, propenso à superação de posições equívocas, bem como aberto ao reencontro da unidade. 
